\title{
Mass balance of the Antarctic ice sheet at Patriot Hills
}

\author{
Gino Casassa, ${ }^{1}$ Henry H. Bregher, ${ }^{2}$ Carlos Círdenas, ${ }^{1}$ Andrés Rivera ${ }^{3}$ \\ ${ }^{1}$ Universidad de Magallanes, Casilla 113-D, Punta Arenas, Chile \\ ${ }^{2}$ Byrd Polar Research Center, The Ohio State University, 1090 Carmack Road, Columbus, OH 43210, U.S.A. \\ ${ }^{3}$ Departamento de Geografía, Universidad de Chile, Marcoleta 250, Santiago, Chile
}

\begin{abstract}
Glaciological data collected at Patriot Hills, Antarctica $\left(80^{\circ} 18^{\prime} \mathrm{S}\right.$, $81^{\circ} 22^{\prime} \mathrm{W}$ ), are used to assess the local mass balance of the ice sheet. The data were collected during two field campaigns conducted by the Instituto Antártico Chileno in January and November 1995. Measurements included surveying of stakes, and ice thickness derived from discrete radar soundings with a ground-based high-frequency impulse system.

Ablation occurred on the bare-ice field at the base of Patriot Hills, with a maximum value of $7 \mathrm{~g} \mathrm{~cm}^{-2} \mathrm{a}^{-1}$. Net accumulation was detected away from the mountains, over the firn-covered area of the glacier, with a maximum rate of $10 \mathrm{~g} \mathrm{~cm}^{-2} \mathrm{a}^{-1}$. Ice thickens rapidly away from the mountains, reaching a thickness of $383 \mathrm{~m}$, the maximum range of the radar system, near the center of the blue-ice field. No significant difference in surface elevation of the ice was detected over the $305 \mathrm{~d}$ period, which indicates that the ice is in near-equilibrium at Patriot Hills.
\end{abstract}

\section{INTRODUCTION}

Patriot Hills is located at the southernmost end of the Ellsworth Mountains, West Antarctica, at $80^{\circ} 18^{\prime} \mathrm{S}, 81^{\circ} 22^{\prime} \mathrm{W}$. It is a small range only $8 \mathrm{~km}$ long, with extensive rock outcrops, especially on its northern flank, and with the highest summit of $1246 \mathrm{~m}$ protruding about $400 \mathrm{~m}$ above the surrounding ice sheet (USGS, 1966). Horseshoe Valley separates Patriot Hills from Douglas Peaks and Wilson Nunataks, the two latter ranges being located about $35 \mathrm{~km}$ north of Patriot Hills. The ice flowing from Horseshoe Valley drains to Hercules Inlet, at the grounding line of the Ronne Ice Shelf, about $50 \mathrm{~km}$ northeast of Patriot Hills.

A bare-ice field about $8 \mathrm{~km}$ long by $2 \mathrm{~km}$ wide exists on the northern side of Patriot Hills. Bare-ice fields, known as blue-ice areas (BIAs), are areas with negative mass balance and comprise only a small part of Antarctica. BIAs are likely to occur in the escarpment region, i.e. an area of relatively steep surface gradient, located between the coast and the interior of Antarctica, where strong winds and low accumulation rates prevail (Van den Broeke and Bintanja, 1995). Ablation is mainly produced by enhanced sublimation over the bare ice, and erosion by divergence of wind-driven snow (Jonsson, 1992; Van den Broeke and Bintanja, 1995). Such ice fields are commonly found in areas near nunataks (Orheim and Lucchitta, 1990), but can occur as well in areas separated from the mountains, where special microclimate conditions exist (Takahashi and others, 1988). Detailed glaciometeorological studies of blue-ice fields have been carried out by the above authors, including heat balance, interaction with katabatic winds and modeling of the climate sensitivity of BIAs.

The blue-ice field of Patriot Hills presents the best conditions in the area for landing with large aircraft on wheels (unpublished information from C.W. M. Swithinbank), having been used for over a decade for logistic purposes, particularly by a private company (Adventure Network International) that has established a large summer camp there.

Glaciological studies in the area of Patriot Hills have been scarce, and mainly limited to accumulation measurements from snow pits dug at a spacing of 50-100 km, along an International Geophysical Year traverse (Bull, 1971); aerial radio-echo sounding (Jankowski and Drewry, 1981); and a few ice-velocity measurements between Independence Hills and Patriot Hills (Ishimaru and others, 1995).

Recently, the Instituto Antártico Chileno (INACH), with the support of the Chilean Air Force, has started a glaciological program aimed at characterizing the massbalance and ice-flow conditions around Patriot Hills (Anonymous, 1995). This paper presents basic results from glaciological measurements carried out during INACH campaigns in the vicinity of Patriot Hills in January and November 1995 (Casassa, 1996).

\section{FIELD MEASUREMENTS}

Base camp was established about $500 \mathrm{~m}$ north of the blue-ice field, near station P5 (Fig. 1). Snowmobiles were used for transportation, with the farthermost station located $6 \mathrm{~km}$ away from the mountains.

\section{Stake traverse}

Three reference points, A, B and E, were established on rock on the northern flank of Patriot Hills, close to the blue-ice field (Fig. 1). From there, 12 stations, between P1 and P9, were established in January 1995, with stakes along a line to the north to a point $6 \mathrm{~km}$ away from the mountains. Of these, four stakes were drilled in the bare ice, and eight stations were placed in firn. All of the stakes were found and remeasured in November 1995. In addition, several new 


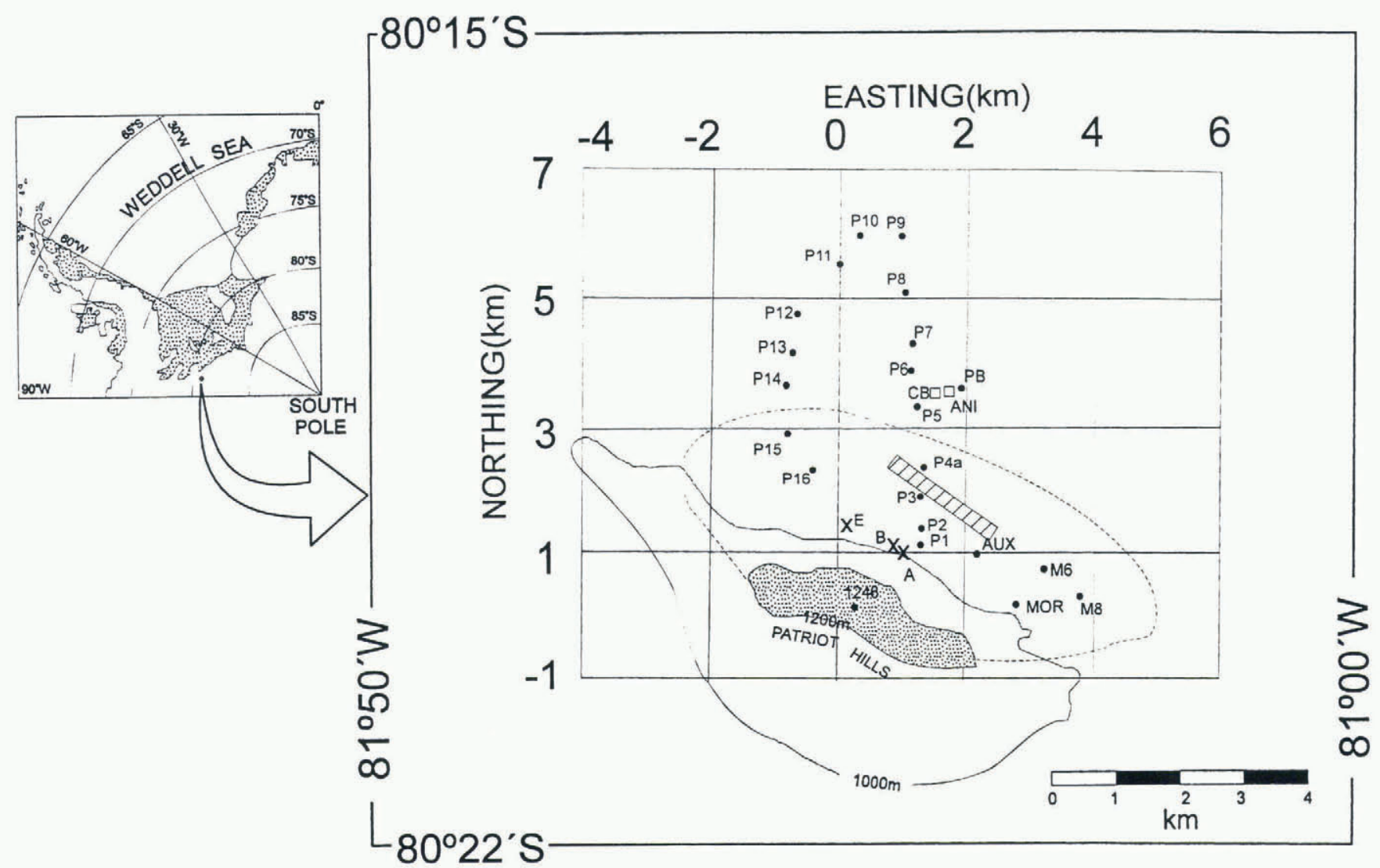

Fig. 1. Map of Patriot Hills, compiled from the USGS (1966) 1:250 000 map sheet and field data. Points A, B and E were installed on rock. MOR is on a lateral moraine. Stakes M1-M5 (not on the map) were installed between MOR and M6, on the blue-ice field. Stakes M7 (not on the map) and M8, P1, P2, P3, P4a, P15 and P16 are located on the blue-ice field. All other stakes were placed on firn. PB and CB are the base camps in January and November 1995, respectively. ANI is the base camp of Adventure Network International. The hatched diagonal band represents the airstrip located on the blue-ice area. The stippled area indicates the main mountain range of Patriot Hills. The dashed line shows the approximate extent of the blue-ice field.

stakes, P10-P16 and M1-M8, were established in November 1995.

A traverse was measured during each epoch, using a local orthogonal coordinate system oriented to geographic north, as measured by sun observations. The origin of the coordinate system is $1000 \mathrm{~m}(\mathrm{~N}), 1000 \mathrm{~m}(\mathrm{E})$ at station A. A Wild T2 theodolite, in combination with a Wild Distomat DI4 electronic distance meter, was used.

Estimated standard errors are $10^{\prime \prime}$ in horizontal and vertical angles and $2 \mathrm{~cm}$ in horizontal distances. At the farthest station (P9), this yields standard errors of $7 \mathrm{~cm}$ in the alongtrack coordinate (approximately northing), $9 \mathrm{~cm}$ in the across-track coordinate (approximately easting) and $13 \mathrm{~cm}$ in elevation.

\section{Radio-echo sounding}

A short-pulse high-frequency (HF) radar system was used, making discrete measurements at each stake. The system was mounted on sledges and towed with a snowmobile, using resistively loaded dipole antennas. The transmitter, constructed at The Ohio State University (Huffman, unpublished), follows the original U.S. Geological Survey design. It consists of a $12 \mathrm{~V}$ power unit, producing an output pulse of $1600 \mathrm{~V}_{\mathrm{pp}}$, a pulse width of about $500 \mathrm{~ns}$, and a repetition rate of $0.2 \mathrm{kHz}$. The transmitter has been used successfully on temperate glaciers (e.g. Jezek and Thompson, 1982; Casassa, 1992). The receiver consisted of a Hitachi VG6045A digital storage oscilloscope connected through a serial port to a notebook personal computer, with a maximum averaging capability of 256 traces.

\section{RESULTS}

\section{Accumulation/ablation}

The height difference of the stakes, measured at each epoch, was used in combination with firn densities obtained in a

Table 1. Ablation/accumulation rates. Negative sign indicates ablation, and height difference is the November minus fanuary value. $P 9 E$ and $P 9 W$ are located $118 \mathrm{~m}$ east and $169 \mathrm{~m}$ west of station $P$ 9, respectively

\begin{tabular}{llrc}
\hline Station & Surface & Height difference & $\begin{array}{c}\text { Ablation/ } \\
\text { accumulation }\end{array}$ \\
& & $\mathrm{cm}$ & $\mathrm{g} \mathrm{cm}^{-2} \mathrm{a}^{-1}$ \\
\hline P1 & Ice & -9 & -7 \\
P2 & Ice & -8 & -6 \\
P3 & Ice & -5 & -4 \\
P5 & Firn & 6 & 2 \\
P6 & Firn & 30 & 10 \\
P7 & Firn & 22 & 7 \\
P8 & Firn & 13 & 4 \\
P9 & Firn & 17 & 6 \\
P9W & Firn & 8 & 3 \\
P9E & Firn & 15 & 5 \\
\hline
\end{tabular}


snow pit at base camp at each epoch to obtain accumulation and ablation rates for the $323 \mathrm{~d}$ period January-November 1995. A mean firn-density value of $376 \mathrm{~kg} \mathrm{~m}^{-3}$ was used, which is an average for the upper $20 \mathrm{~cm}$ layer between January and November. An ice density of $917 \mathrm{~kg} \mathrm{~m}^{-3}$ was used for the blue-ice field. Table 1 shows the results.

As anticipated, ablation occurs on the blue-ice field, being maximum at the southern edge of the ice, close to the mountains ( $\mathrm{Pl})$. A large part of the ablation is expected to occur by sublimation (Jonsson, 1992), although some melting does happen during the summer, perhaps not every year but probably during very warm events, as evidenced by frozen pools found at the southern edge of the blue-ice field. However, relative amounts of sublimation and melting cannot be assessed, due to lack of heat-balance measurements.

At station P5, located near the northern edge of the ice field, accumulation is minimum. A large variation in snow accumulation can be observed north of P5. Probably this does not reflect a spatial variation of accumulation rate, but is due to random sastrugi formation. Therefore, a representative accumulation rate in this area is $6 \mathrm{~g} \mathrm{~cm}^{-2} \mathrm{a}^{-1}$, obtained by averaging the values for stakes $\mathrm{P} 6-\mathrm{P} 9 \mathrm{E}$. This is much smaller than the value of $15 \mathrm{~g} \mathrm{~cm}^{-2} \mathrm{a}^{-1}$ indicated by Giovinetto and Bull (1987) for the area. However, Giovinetto and Bull based their results on snow-pit data collected at a spacing of 50-100 km (Bull, 1971), which is representative of the ice sheet rather than the area near the mountains.

Our results indicate that snow accumulation around Patriot Hills is reduced by a factor of 2.5 as compared with the value of the surrounding ice sheet. Although on the blue-ice field sublimation certainly contributes to ablation of the accumulated snow, there is sufficient field evidence to suggest that the prevailing southwest katabatic wind results in erosion by divergence of wind-driven snow (Van den Broeke and Bintanja, 1995) leeward of Patriot Hills. In fact, preliminary wind measurements indicate a 20-50\% wind-velocity increase on the blue-ice field compared to the base camp site, located $500 \mathrm{~m}$ south of the edge of the blue ice. This is also evidenced by the size of sastrugi, which are clearly smaller away from the mountains, toward the north. Amplitudes of sastrugi of $40 \mathrm{~cm}$ are not uncommon just north of the blue-ice field, decreasing rapidly to the north, and becoming much subdued a few kilometers away from the mountains.

\section{Surface-elevation changes}

The resurvey of the $\mathrm{P}$ traverse allowed elevation differences of the glacier surface to be computed over the period of 305 d between 15 January and 17 November 1995. Estimated errors in elevation $\left(m_{\mathrm{e}}\right)$ for each epoch are $3 \mathrm{~cm}$ at station $\mathrm{Pl}$ and $13 \mathrm{~cm}$ at station P9, so the standard error for the elevation-change values is $7 \mathrm{~cm}$ for $\mathrm{Pl}$ and $18 \mathrm{~cm}$ for $\mathrm{P} 9$.

Measurements were carried out at the stakes, which moved with the glacier, so elevation changes do not exactly reflect surface changes at the same location. However, since surface slopes and ice speeds are small $\left(\sim 1 \%\right.$ and $\sim 5 \mathrm{ma}^{-1}$ at station P9, respectively), the associated error is negligible with respect to measurement errors, with a maximum error due to advection of $4 \mathrm{~cm}$ at P9 for the period JanuaryNovember.

Elevation changes are shown in Table 2. Elevation changes at stations P6 and P7 appear to be significant. However, they occur in an area where sastrugi have amplitudes
Table 2. Elevation changes (November minus January)

Station

Elevation change

$\mathrm{cm}$

$\begin{array}{lr}\text { P1 } & 9 \\ \text { P2 } & 13 \\ \text { P3 } & 10 \\ \text { P4a } & 14 \\ \text { P5 } & 14 \\ \text { P6 } & 36 \\ \text { P7 } & 20 \\ \text { P8 } & 2 \\ \text { P9 } & -9 \\ \text { P9W } & -16 \\ \text { P9E } & -11\end{array}$

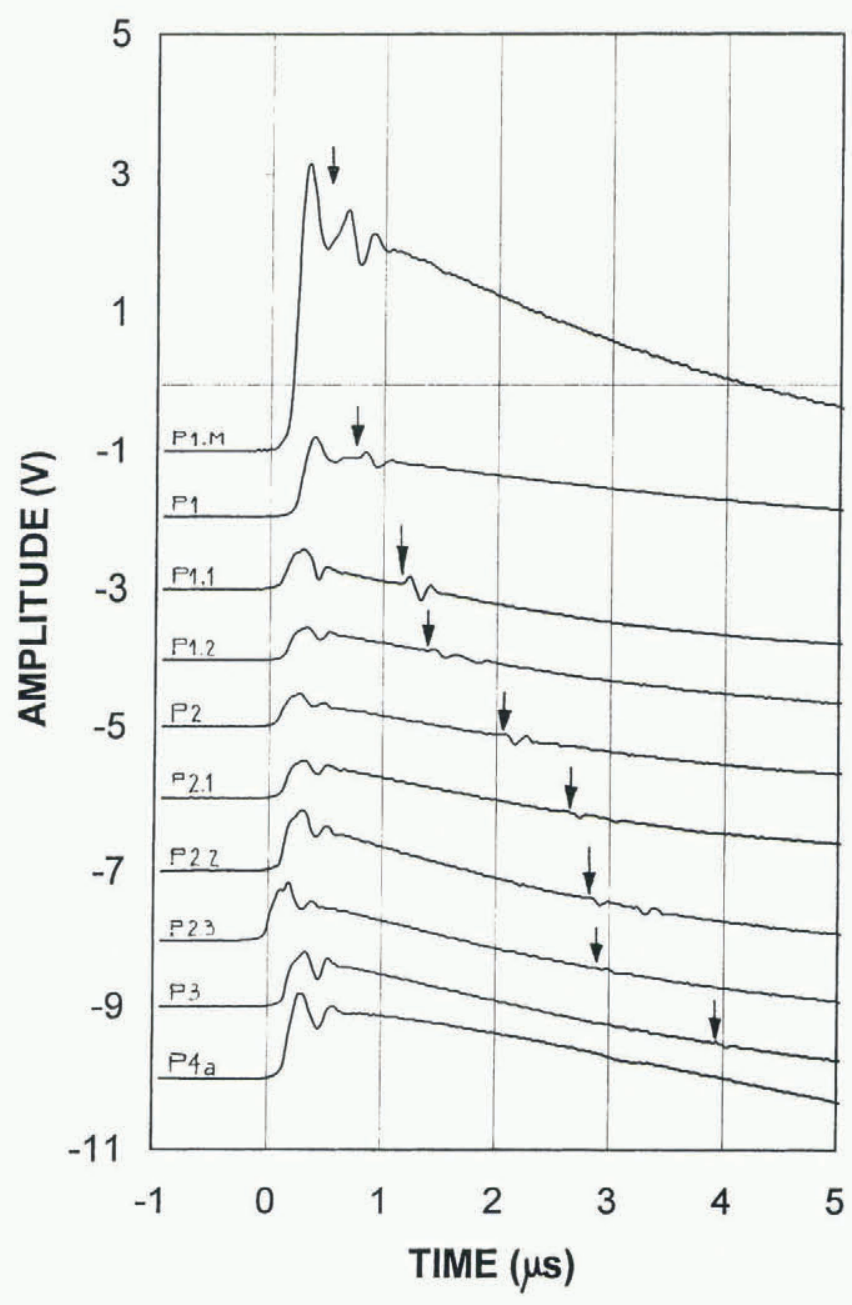

Fig. 2. Radar traces for transect P. The uppermost trace was measured at the edge of the blue-ice field, close to the mountains of Patriot Hills. Labels correspond to stations indicated in Figure 1. Intermediate stations where no stakes were installed in the field are labeled P1.1, P1.2, etc. The large signal between 0 and $0.5 \mu$ s corresponds to the surface wave transmitted on the air-ice interface. The small signals to the right of the surface wave, between 0.5 and $4.5 \mu$ s, correspond to bed returns, indicated by arrows, which are progressively deeper away from the mountains. At P4a no bed return could be detected. The bed returns were amplified for graphic purposes. The amplitude scale is shown for reference, with relative values, in volts, being valid only for the surface wave. 
up to $40 \mathrm{~cm}$, due to strong wind in the vicinity of the mountains, as mentioned earlier. Because sastrugi can migrate and/or form randomly, we consider that uncertainty in detecting elevation changes can be as high as $0.5 \mathrm{~m}$ near the blue-ice field. Since no elevation change greater than $36 \mathrm{~cm}$ occurred in the vicinity of Patriot Hills during the $305 \mathrm{~d}$ period, this indicates a zero mass balance within our uncertainty for the area.

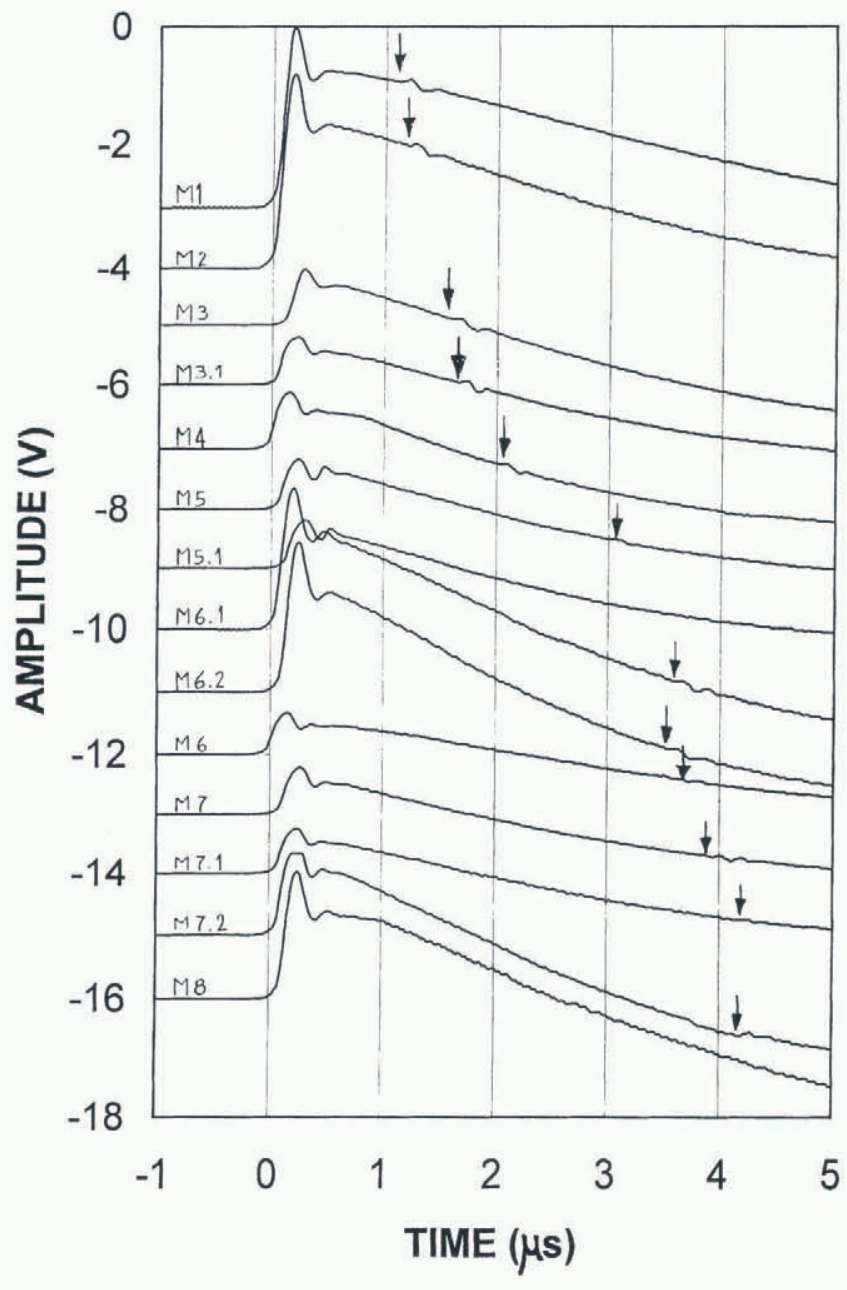

Fig. 3. Radar traces for transect M. See Figure 2 caption for explanation. At M8 no bed echo could be detected.

\section{Radar measurements of ice thickness}

Traces of radar data for transects $\mathrm{P}$ and $\mathrm{M}$ are shown in Figures 2 and 3 . In these figures, the time origin, or zero-time, corresponds to the arrival time of the surface wave, transmitted to the receiver along the air/ice interface. Bed returns are seen on the trace diagrams as sinusoidal signals with small amplitude, which have an increasingly large return time as the ice gets deeper away from the mountains.

Ice depth ( $D$, in m; Figs 4 and 5) was calculated from the return time $\left(t_{\mathrm{r}}\right.$, in $\left.\mu \mathrm{s}\right)$ using the following equation, modified from Watts and Isherwood (1978):

$$
D=\frac{1}{2} \sqrt{\left[v_{\mathrm{i}}\left(t_{\mathrm{r}}+\frac{s}{c}\right)\right]^{2}-s^{2}}
$$

where $v_{\mathrm{i}}$ is the speed of electromagnetic wave in cold ice (168 $\mathrm{m} \mathrm{s}^{-1}$; Matcheret and others, 1993), $s$ is the antenna separation ( $36 \mathrm{~m}$ at transect $\mathrm{P}$, and $31.5 \mathrm{~m}$ at transect $\mathrm{M}$ ) and $c$

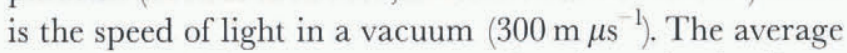
error in ice-thickness measurement is estimated to be $15 \mathrm{~m}$.

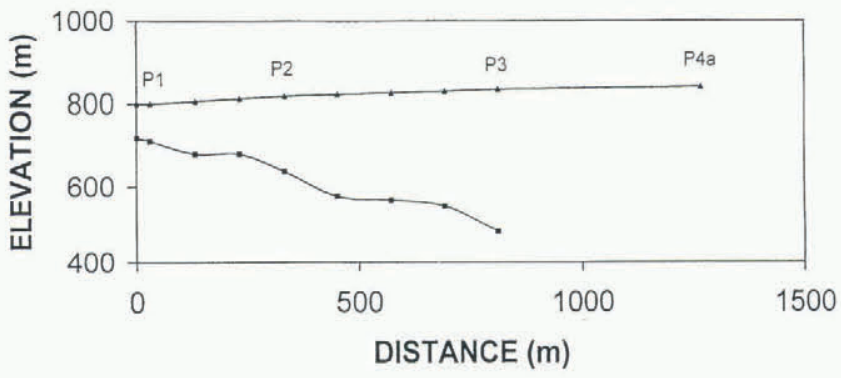

Fig. 4. Profile of the glacier for transect P. Points correspond to field measurements. Ice depth was obtained from return times (Fig. 2) using the equation described in the text. The distance origin is located at the edge of the blue-ice field, close to the mountains.

Along transect $\mathrm{P}$, radar data were recorded at stakes $\mathrm{P} 1-$ $\mathrm{P} 4 \mathrm{a}$, including intermediate stations (Figs 2 and 4). In spite of repeated measurements using different antenna configurations and orientations, recording 256 traces and using the highest oscilloscope sensitivity $(2 \mathrm{mV} / \mathrm{div})$, no bottom echoes could be detected beyond stake P3, near the center line of the blue-ice field. A maximum ice thickness of $351 \mathrm{~m}$ could be detected at station P3 (Fig. 4).

Transect M was set up in the southeastern part of the blue-ice field (Fig. 1), in order to have a more detailed icethickness distribution. The $\mathrm{M}$ transect has a northeast direction from $\mathrm{Ml}$ to $\mathrm{M} 6$, and then turns $90^{\circ}$ to the southeast, toward station M8. A maximum ice thickness of $383 \mathrm{~m}$ was detected at station M7.2 (Fig. 5). This value corresponds to the maximum range of the radar.

Ice-thickness values of about $1300 \mathrm{~m}$ exist toward the center of Horseshoe Valley, the valley separating Patriot Hills from Douglas Peaks, the latter being located $30 \mathrm{~km}$ northward (Vaughan and others, 1994), which shows that the present HF impulse radar system needs substantial modifications to sound deeper ice.

Bed profiles (Figs 4 and 5) show an increase in ice thickness away from the mountains, with an average bed slope of $4 \%$ at the farthest point where ice thickness could be measured (P3 and M6 in Figs 4 and 5, respectively). However, flatter subglacial areas are seen between stations P1 and P2, north of P2, and between M3 and M4. It is unknown whether these features are due to present erosional or depositional processes at the glacier bed or reflect instead conditions prior to the formation of the ice sheet.

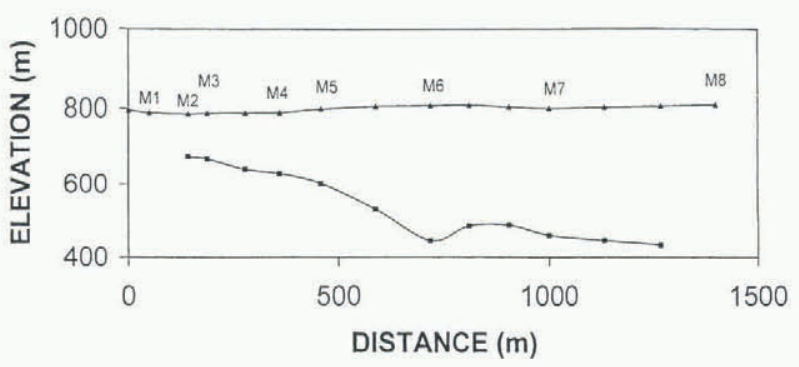

Fig. 5. Profile of the glacier for transect M. See explanation for Figure 4. The distance origin is located at the edge of the blue-ice field, at station MOR, on the lateral moraine (Fig. 1). The bed-slope change at station M6 is due to a $90^{\circ}$ change in the transect direction, as can be seen in Figure 1, and explained in the text. 


\section{CONGLUSIONS}

Glaciologic data collected in the vicinity of Patriot Hills allow the accumulation rate in the area to be characterized. The presence of the mountains exerts a strong influence on the accumulation pattern, probably by divergence of winddriven snow flux, which results in reduced accumulation. Accumulation rate increases away from the mountains, with ablation occurring over the blue-ice field and accumulation in the firn area.

A maximum ice thickness of $383 \mathrm{~m}$ was measured with the HF impulse radar system, near the center of the blueice field. Modifications are needed in the receiving and transmitting units of the radar system in order to increase the sounding range.

Precise repeat measurements of stake heights after a 305 d period show no significant elevation difference, which indicates a near-zero mass balance for the ice sheet at Patriot Hills.

\section{ACKNOWLEDGEMENTS}

INACH sponsored the field expedition, as part of INACH project No. 158, "Glaciological Studies in Patriot Hills". The Chilean Air Force provided air transportation and valuable logistic support in the field. Data analyses were completed at Universidad de Magallanes. A. Oyaneder drew Figure 1. Valuable comments were made by R. A. Bindschadler and an anonymous referee.

\section{REFERENCES}

Anonymous. 1995. INACH; a 1,084 km del Polo Sur. Boletín Antártico Chileno, 14(1), 17-19.

Bull, C. 1971. Snow accumulation in Antarctica. In Quam, L. O., ed. Research in the Antarctic. Washington, DC, American Association for the Advancement of Science, 367-421. (Publication 93.)
Casassa, G. 1992. Radio-echo sounding of Tyndall Glacier, southern Patagonia. Bull. Glacier Res. 10, 69-74.

Casassa, G. 1996. Expedición INACH a Patriot Hills, noviembre-diciembre 1995. Boletín Antártico Chileno, 15(1), 20-24.

Giovinetto, M. B. and C. Bull. 1987. Summary and analyses of surface mass balance compilations for Antarctica, 1960-1985. Byrd Polar Research Center Report 1 .

Huffman, F. E. Unpublished. Marx generator for high frequency ice radar system. Columbus, OH, Ohio State University. Department of Geological Sciences.

Ishimaru, A., K. Yoshikawa, K. Kizaki and K. Harada. 1995. Observations of moraine at the foot of Independence Hills in the southern Ellsworth Mountains, Antarctica. In Yoshikawa, K., K. Harada and A. Ishimaru, eds. Scientific results from the Antarctic Walk Environmental Research Expedition 1991-1993. Tokyo, Antarctic Environmental Research Expedition Organizing Committee, 17-32.

Jankowski, E. J. and D. J. Drewry. 1981. The structure of West Antarctica from geophysical studies. Nature, 291 (5810), 17-21.

Jezek, K. C. and L. G. Thompson. 1982. Interpretation of monopulse ice radar soundings on two Peruvian glaciers. IEEE Trans. Geosci. Remote Sensing, GE-20 (3), 243-249.

Jonsson, S. 1992. Local climate and mass balance of a blue-ice area in western Dronning Maud Land, Antarctica. Z Gletscherkd. Glazialgeol., 26(1), 1990, 11-29.

Macheret, Yu. Ya., M. Yu. Moskalevsky and E. V. Vasilenko. 1993. Velocity of radio waves in glaciers as an indicator of their hydrothermal state, structure and regime. 7. Glaciol., 39(132), 373-384.

Orheim, O. and B. Lucchitta. 1990. Investigating climate change by digital analysis of blue ice extent on satellite images of Antarctica. Ann. Glaciol., 14, 211-215.

Takahashi, S., R. Naruse, M. Nakawo and S. Mae. 1988. A bare ice field in east Queen Maud Land, Antarctica, caused by horizontal divergence of drifting snow. Ann. Glaciol., 11, 156-160.

United States Geological Survey (USGS). 1966. Liberty Hills. Washington, DC, U.S. Department of the Interior. U.S. Geological Survey. (Reconnaissance Series, Scale 1:250 000.)

Van den Broeke, M. R. and R. Bintanja. 1995. The interaction of katabatic winds and the formation of blue-ice areas in East Antarctica. 7. Glaciol., 41 (138), 395-407.

Vaughan, D. G. and 9 others. 1994. Map of subglacial and seabed topography, Filchner/Ronne Schelfeis/Weddell Sea, Antarktis. 1:2,000,000. Frankfurt am Main, Institut für Angewandte Geodäsie.

Watts, R. D. and W. Isherwood. 1978. Gravity surveys in glacier-covered regions. Geophysics, 43(4), 819-822. 